\title{
Surgical correction of degenerative lumbosacral stenosis in a puma (Puma concolor araucana)
}

\author{
Corrección quirúrgica de estenosis lumbosacral degenerativa en un puma
}

(Puma concolor araucana)

\author{
C Verdugo $^{a^{*}}$, M Gómez ${ }^{b}$, M Alvarado-Rybak ${ }^{c}$, H Bustamante ${ }^{d}$, L Cardona $^{d}$, M Mieres $^{d}$ \\ ${ }^{a}$ Centro de Rehabilitación de Fauna Silvestre, CEREFAS, Facultad de Ciencias Veterinarias, \\ Universidad Austral de Chile, Valdivia, Chile. \\ bInstituto de Farmacología y Morfofisiología, Facultad de Ciencias Veterinarias, Universidad Austral de Chile, Valdivia, Chile. \\ 'Instituto de Patología Animal, Facultad de Ciencias Veterinarias, Universidad Austral de Chile, Valdivia, Chile. \\ Instituto de Ciencias Clínicas Veterinarias, Facultad de Ciencias Veterinarias, Universidad Austral de Chile, Valdivia, Chile.
}

\section{RESUMEN}

\begin{abstract}
Un ejemplar de puma (Puma concolor araucana) macho intacto, adulto (12 años), fue evaluado debido a una paraparesis y deambulación anormal de los miembros pélvicos. Al examen neurológico se determinó una paraparesia progresiva, ataxia simétrica de los miembros pélvicos y parálisis de la cola. Se obtuvieron radiografías simples y una tomografía computarizada (TC) del segmento lumbosacro como exámenes diagnósticos para determinar posibles causas. El examen de TC confirmó una estenosis del canal vertebral en el segmento vertebral L7-S1. Se realizó una laminectomía dorsal con el fin de descomprimir el área afectada. Se tomaron muestras de tejido blando del área afectada para su análisis histopatológico. El material colectado presentó moderadas células inflamatorias e hipertrofia del ligamento flavum. Dos semanas después de la cirugía, el animal mostró un mejoramiento neurológico progresivo y retornó a una ambulación normal.
\end{abstract}

Key words: cougar, laminectomy, ligamentum flavum, lumbosacral compression, Puma concolor.

Palabras clave: laminectomía, ligamento flavum, compresión lumbosacra, puma, Puma concolor.

\section{INTRODUCTION}

Degenerative Lumbosacral Stenosis (DLSS) is a spinal disorder commonly reported as a clinical syndrome in domestic dogs, although is rarely recognized in felines (De Risio et al 2000). Compressive lesions at the cauda equina (i.e. sacral caudal and L7 spinal nerve and nerve roots) (De Risio et al 2000) combined with other abnormalities (e.g. trauma, vascular causes, infectious and inflammatory diseases, and neoplasia), lead to degenerative changes including soft tissue hypertrophy of supporting ligamentous structures such as the ligamentum flavum (Sharp and Wheeler 2005). The DLSS or lumbosacral syndrome may cause signs in the pelvic limbs, bladder, anal sphincter, and tail innervations. These can range from flaccid weakness to paralysis of pelvic limbs, including reluctance to movement, pelvic limb gait abnormalities, uni or bilateral lameness, paraesthesia or dysesthesia, tail paresis or paralysis, and urinary or fecal incontinence (De Risio et al 2000). However, the most consistent clinical sign is lumbosacral pain, indicated by characteristic postures which increases the diameter of the vertebral canal,

Aceptado: 19.01.2011.

* College of Veterinary Medicine, University of Florida, Gainesville, FL 32610, USA; Casilla 567, Valdivia, Chile; cverdugo@ufl.edu and decreases the spinal nerve compression (Danielsson and Sjöström 1999, Sharp and Wheeler 2005). Here, we describe a clinical case and successful surgical treatment of DLSS in a puma (Puma concolor araucana) caused by the hypertrophy of the L7-S1 ligamentum flavum.

\section{MATERIAL AND METHODS}

\section{CASE REPORT}

A 12 year old, 53-kg intact male puma (Puma concolor araucana) was presented to the Veterinary Teaching Hospital at Universidad Austral de Chile, Valdivia, Chile, because of pelvic limb paraparesis and walking difficulty of two weeks duration. The animal came from a private reproduction center, where it was housed separately with one other puma, and was provided with beef and water ad libitum. During the examination the animal was alert and responsive but showed evident ambulatory difficulty, crouched stance, reluctance to rise and jump, symmetric pelvic limb ataxia, and tail paralysis. In addition, there was a decreased muscle tone and atrophy of the pelvic limb muscles, whereas thoracic limb muscle tone was normal. Patellar reflexes were normal but flexor reflexes of the pelvic limbs were decreased. Because of the nature of the animal, further visual and palpable examinations 
and diagnostic procedures were only achievable with the anesthetized animal. The animal was immobilized with a combination of medetomidine ${ }^{1}(0.04 \mathrm{mg} / \mathrm{kg}$, I.M.) and ketamine $^{2}$ (3 mg/kg, I.M.), and then it was intubated and maintained with isofluorane ${ }^{3}(1-3 \%)$ in oxygen. There were no palpable abnormalities of the vertebral column and pelvic limbs. Head, thoracic and abdominal physical examinations were also normal. CBC and plasma biochemistry profile were unremarkable. Based on the clinical signs, the neuroanatomic diagnosis indicated Lower Motor Neuron (LMN) deficit of the tail musculature (caudal nerves) and caudal thigh and crural musculature (sciatic nerve) indicating compromise of the L6, L7, sacral and caudal spinal cord segments, the spinal roots and spinal nerves. Differential diagnosis included external injury, degenerative lumbosacral stenosis, intervertebral disk disease, diskospondylitis, myelitis, neoplasia, fibrocartilaginous embolic myelopathy or thromboembolism. Survey radiographs of the vertebral column revealed sclerosis of the articular facets of L7-S1, as well as an increase of radiographic density similar to soft tissue in the vertebral canal between L7-S1. A computed tomographic $^{4}(\mathrm{CT})$ scan of the lumbosacral region was performed with the animal in dorsal recumbency with flexed pelvic limbs. Transverse soft tissue CT images showed loss of epidural fat in the $\mathrm{L}_{7}-\mathrm{S}_{1}$ vertebral canal and increased soft tissue opacity dorsally at the location of the ligamentum flavum (LF) (figure 1). Although dynamic studies were not performed in this clinical case to evaluate instability of the lumbosacral joint, anatomical variations were not evident at the CT images. Bone window images revealed smooth bone margins, but marked dorsoventral stenosis of the $\mathrm{L}_{7}-\mathrm{S}_{1}$ vertebral canal, with no evidence of a dynamic lesion. Epaxial muscles over the affected area were symmetrically atrophied. Based on the above findings, a spinal surgical decompression was performed the following day, using the same anesthetic procedure, with an epidural regional analgesia using lidocaine ${ }^{5}(2 \mathrm{mg} / \mathrm{kg}$ diluted in $10 \mathrm{ml}$ of saline solution). A dorsal midline incision was made over the caudal lumbar spine with the animal in sternal recumbency. A dorsal laminectomy and osteotomy of spinous process of $\mathrm{L}_{7}$ and the median sacral crest, with preservation of vertebral pedicles and articular facets (Funkquist type B) was performed using rongeurs and a high-speed burr. The sacral and caudal spinal nerves were displaced ventrally by abundant connective tissue from the LF. All the compressive soft tissue was removed by sharp dissection using a surgical blade No. 15 and the retraction was done with Adson-Brown forceps; then the area was

Domitor ${ }^{\circledR}$, Pfizer, Exton, Pennsylvania 19341, USA

Ketostop, Drag-Pharma, Invetec S.A., Santiago 0675645, Chile.

Isoflorano USP, Baxter Health Care Corporation, Guayama, Puerto Rico 00784, USA.

$4 \quad 4^{\text {th }}$ generation CT scanner, IQ/PQ 4.25 Diagnostics, Picker International Inc., Cleveland, Ohio 44143, USA.

5 Lidocaína 2\%, Laboratorio Chile, Santiago 7780050, Chile.

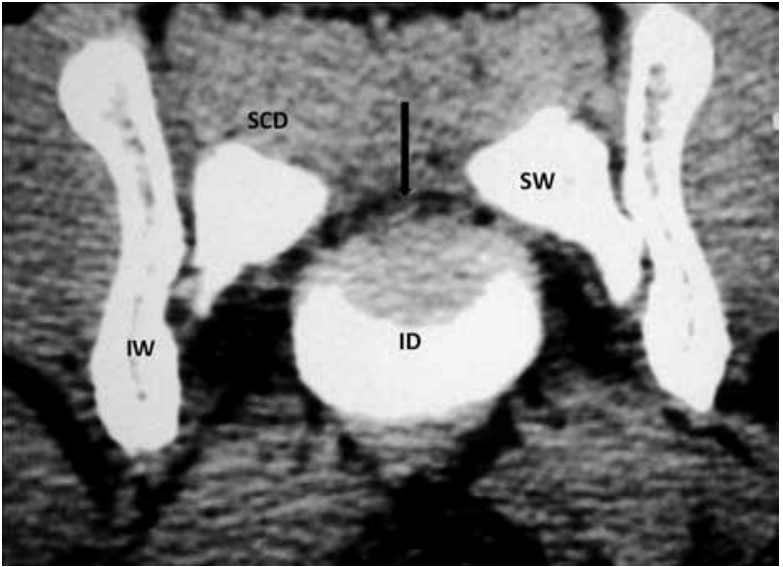

Figure 1. Transverse soft tissue window CT image at L7-S1 vertebral canal from a puma (Puma concolor araucana) showing evident dorso-ventral narrowing of the vertebral canal and decrease of epidural fat (arrow) (IW: ilial wing; ID: L7-S1 intervertebral disk; SW: sacral wing; SCD: right sacrocaudalis dorsalis lateralis muscle).

Imagen transversa de tomografía computarizada (TC) obtenida a nivel del canal vertebral de L7-S1 en un puma (Puma concolor araucana) adulto en donde se muestra evidente estrechamiento dorsoventral del canal vertebral y una disminución de grasa epidural (flecha) (IW: alas del ilion; ID: disco intervertebral L7-S1; SW: ala sacral; SCD: músculo sacrocaudalis dorsalis lateralis derecho).

irrigated with sterile isotonic saline. After decompression repair, sacral and caudal spinal nerves returned to their normal anatomic positions. A fat graft harvested from the subcutaneous tissue was placed into the defect of the laminectomy. Muscular, subcutaneous and skin planes were closured routinely. All collected tissue was placed in $10 \%$ buffered formalin for histologic examination. Postoperative treatment included ketoprofen ${ }^{6}$ ( $1 \mathrm{mg} / \mathrm{kg}$, q24h, I.M.), and amoxicillin with clavulanic acid ${ }^{7}$ (7mg/kg, q24h, I.M.) for five days. To minimize postsurgical complications the animal was kept in a space-limited cage for two weeks. The locomotion of the animal and the tail movements improved within three days after surgery. In two weeks, the animal recovered its normal ambulation and was moved to his definitive captivity place. Histologic examination of the tissue samples collected from the LF at surgery and stained with hematoxilin-eosin revealed adipocytes surrounded by abundant dense connective tissue, predominantly thick collagen bands, moderate level of lymphocytes, neutrophils, and erythrocytes infiltrates, and proliferation of blood vessels (figure 2). In order to determine the composition of the connective tissue found in the samples, two different stains were prepared: Heidenhain-Azan $(\mathrm{H}-\mathrm{A})$ and Verhoeff stain targeting collagen fibers and elastic fibers, respectively, also allowing the evaluation of the amount and condition of these tissues. H-A stained samples indicated abundant collagen band proliferation and scarce elastic

Ketofen, 10\%, Merial SAS, Lyon F-69348 Cedex 07, France. Mastilac, Pfizer Inc, New York, New York 10017 USA. 


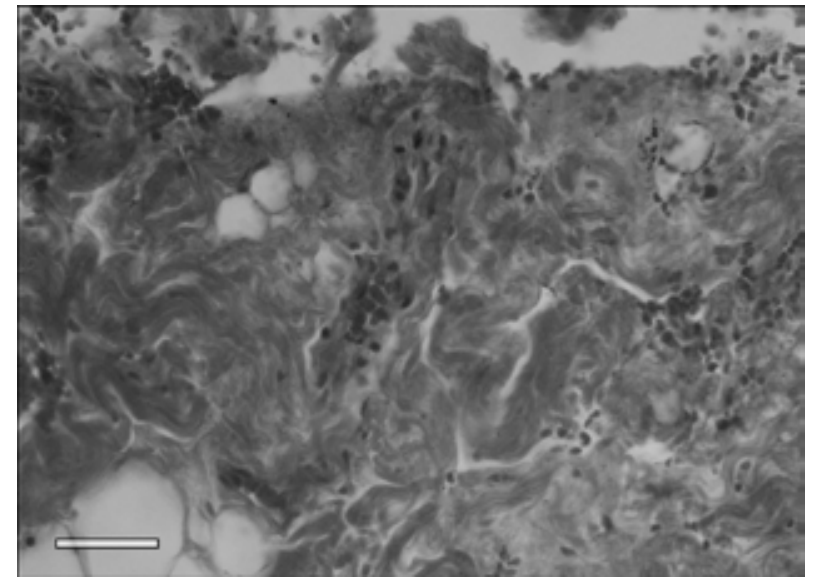

Figure 2. Tissue removed from L7-S1 by laminectomy in a puma (Puma concolor araucana) revealing abundant dense connective tissue, mainly collagen bands, infiltrated by neutrophils, lymphocytes, and erythrocytes. Haematoxylin \& Eosin stain. Scale bar $=60 \mu \mathrm{m}$.

Tejido removido del segmento L7-S1 por laminectomía en un puma. Se observa abundante tejido conectivo denso, principalmente bandas de colágeno, infiltrado neutrofílico, linfocitario y eritrocítico. Tinción de hematoxilina y eosina. Barra de escala $=60 \mu \mathrm{m}$.

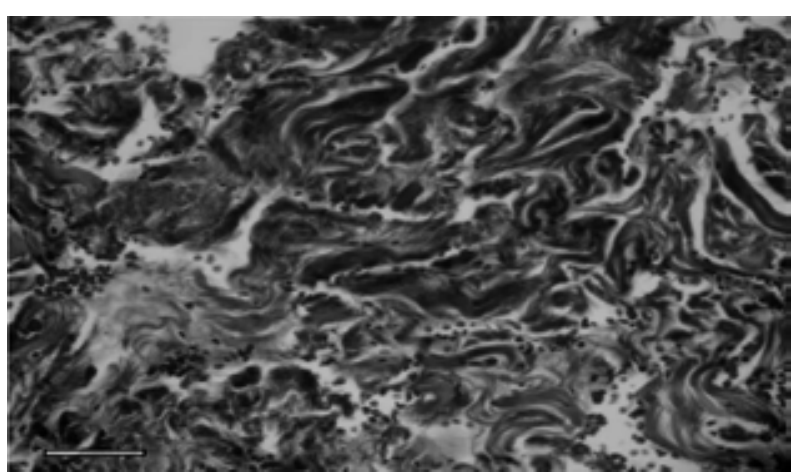

Figure 3. Tissue removed from L7-S1 by dorsal laminectomy in a puma (Puma concolor araucana) showing irregular and abundant collagen bands. Elastin fibers (light gray), usually in a more equal ratio, are replaced by a proliferation of collagen fibers (dark gray). Heidenhain-Azan stain. Scale bar $=60 \mu \mathrm{m}$.

Tejido removido del segmento L7-S1 por laminectomía en un puma (Puma concolor araucana). La tinción Heidenhain-Azan permite observar abundantes bandas de colágeno de distribución irregular. Usualmente, las fibras de elastina (gris claro) se presentan a razón 1:1, sin embargo, han sido reemplazadas por la proliferación de fibras de colágeno (gris oscuro). Barra de escala $=60 \mu \mathrm{m}$.

fibers (figure 3). Additionally, Verhoeff stained samples showed profuse collagen band proliferation. Based on these findings, a DLSS caused by inflammation and hypertrophy of LF was diagnosed.

\section{DISCUSSION}

Although DLSS lesions are commonly reported in the canine patient (Sharp and Wheeler 2005), these conditions are rarely reported in cats (Cariou et al 2008). Captive non domestic felids, however, can be prone to spinal disease because of inadequate exercise, obesity, and inappropriate enclosure surfaces (Kolmstetter et al 2000). In dogs, the most common causes of cauda equina compression are age-related pathologic changes including DLSS (De Risio et al 2005, Danielsson and Sjöström 1999). Degenerative changes, such as soft tissue overgrowth of ligamentous structures, are thought to result from the considerable transfer of forces and high mobility of the lumbosacral joint, mainly by flexion movements between L7 and the sacrum (Sharp et al 2005, De Risio et al 2005). Degenerative changes lead to compensatory skeletal changes such as lumbosacral end plate sclerosis, articular facet osteophytes, LF and joint capsule hypertrophy, and dorsal annulus bulging, producing clinical problems by spinal cord or spinal nerve compression (De Risio et al 2005). Animals with DLSS show decreased lumbosacral mobility due, in part, to LF hypertrophy compressing the cauda equina. The termination of the spinal cord (conus medullaris) and cauda equina apparently is variable in felines ranging from caudal border of L7 vertebrae to the caudal border of S3 vertebrae (Dyce et al 2004). The LF also known as the interacuate or yellow ligament connects the space between the lamina of adjacent vertebrae. The extracellular matrix of normal LF is composed of parallel elastin and collagen fibers (e.g. in humans, elastin:collagen are in a 2:1 ratio) (Kosaka et al 2007). The elastin fibers provide elasticity and the collagen provides stiffness and stability (Kosaka $e t$ al 2007). In cases of LF hypertrophy, this ratio decreases resulting in a poor elasticity and augmented stiffness or fibrosis (Kosaka et al 2007, Sairyo et al 2007). The causes of LF hypertrophy are multifactorial and include age, activity levels, and mechanical stress. Mechanical loading causes minor injury of the LF inducing inflammation and degeneration of the tissue. During wound healing, inflammation leads to scar formation. In this case, there was a notable increase in collagen and decrease in elastic fibers, with a loss of the parallel arrangement of cells. The latter change increases ligament volume and has also been described in humans as age-related changes (Kosaka et al 2007, Sairyo et al 2007, Schräder et al 1999). Fibrosis is a type of scarring resulting from injury. This animal with hypertrophied ligaments is, therefore, likely to have suffered a stress- and age-related injury leading to scar formation and clinical signs. Expression of inflammatory cytokines, including COX-2, and IL-1, 6, 8, and 15, has been detected in human LF tissue (Sairyo et al 2007). Thus, future studies may be directed to determine whether hypertrophy of LF in feline patients can be a controllable condition at least to some extent, by controlling the scar formation with drugs such as COX-2 inhibitors or steroids. In conclusion, this report confirms degenerative changes of the ligamentum flavum resulting in lumbosacral syndrome in a puma. These changes should be considered as a differential diagnosis for pelvic limb paresis in elderly patients and may be surgically managed in order to reduce vertebral canal stenosis. 


\section{SUMMARY}

A 12-year-old adult, intact male puma (Puma concolor araucana) was evaluated because of abnormal hind limb gait and paresis Neurological examination revealed a progressive paraparesis, bilateral pelvic limb proprioceptive deficit and tail paralysis. Survey radiographs and computed tomography $(\mathrm{CT})$ were taken at the lumbosacral region in order to determine possible causes. CT study confirmed a stenotic vertebral canal at the L7/S1 level. A dorsal laminectomy was performed in order to decompress the affected area. Histopathologic examination of the harvested material revealed inflammation and hypertrophy of the ligamentum flavum. Two weeks after the surgery, the puma showed progressive neurologic improvement and normal ambulation.

\section{REFERENCES}

Cariou M, C Störk, A Petite, R Rayward.2008. Cauda equina syndrome treated by lumbosacral stabilisation in a cat. Vet Comp Orthop Traumatol 21, 462-466.

Danielsson F, L Sjöström. 1999. Surgical treatment of degenerative lumbosacral stenosis in dogs. Vet Surg 28, 91-98.
De Risio L, W Thomas, N Sharp. 2000. Degenerative lumbosacral stenosis. Vet Clin North Am Small Anim Pract 30, 111-132.

Dyce KM, WO Sack, CJ Wensing. 2002. The neck, back, and vertebral column of the carnivores. In: Textbook of Veterinary Anatomy. $3^{\text {rd }}$ ed. WB Saunders, Philadelphia, USA, Pp 400-401.

Kolmstetter C, L Munson, E Ramsay. 2000. Degenerative spinal disease in large felids. J Zoo Wildl Med 31, 15-19.

Kosaka H, K Sairyo, A Biyani, D Leaman, R Yeasting, K Higashino, T Sakai, S Katoh, T Sano, V Goel, N Yasui. 2007. Pathomechanism of loss of elasticity and hypertrophy of lumbar ligamentum flavum in elderly patients with lumbar spinal canal stenosis. Spine 32, 2805-2811.

Sairyo K, A Biyani, V Goel, D Leaman, R Booth, J Thomas, N Ebraheim, I Cowgill, S Mohan. 2007. Lumbar ligamentum flavum hypertrophy is due to accumulation of inflammation-related scar tissue. Spine 32, E340-E347.

Schräder PK, D Grob, BA Rahn, J Cordey, J Dvorak. 1999. Histology of the ligamentum flavum in patients with degenerative lumbar spinal stenosis. Eur Spine J 8, 323-328.

Sharp NJ, SJ Wheeler. 2005. Small Animal Spinal Disorders: Diagnosis and Surgery. $2^{\text {nd }}$ ed. Elsevier Mosby, Oxford, UK. 